\title{
BULUT OR BASAH? WHICH WET IS PRESERVED? AN INVESTIGATION OF DISAPPEARING ACEHNESE ADJECTIVES AMONG YOUNG SPEAKERS
}

\author{
Kismullah Abdul Muthalib ${ }^{1^{*}}$, Tengku Maya Silviyanti ${ }^{2}$, Reza Fahlevi ${ }^{3}$ \\ ${ }^{1 *}$ Lecturer, Department of English Education, Faculty of Teacher Training and Education, Universitas Syiah Kuala, \\ Banda Aceh, Indonesia; ${ }^{2}$ Lecturer, Department of English Education, Faculty of Teacher Training and Education, \\ Universitas Syiah Kuala, Banda Aceh, Indonesia; ${ }^{3}$ Student, Department of English Education, Faculty of Teacher \\ Training and Education, Universitas Syiah Kuala, Banda Aceh, Indonesia. \\ Emails: ${ }^{1 *}$ kismullah@unsyiah.ac.id, ${ }^{2}$ tgk_maya@unsyiah.ac.id, ${ }^{3}$ reza.faijo1983@gmail.com
} Article History: Received on $24^{\text {th }}$ March 2020, Revised on $28^{\text {th }}$ April 2020, Published on $21^{\text {st }}$ May 2020

\section{Abstract}

Purpose of the study: This study was aimed at finding out the potentially disappearing adjectives in Acehnese and the reasons that may contribute to the disappearance by looking at the backgrounds of participants and their language use.

Methodology: This is a sociolinguistic study employing questionnaires, wordlist interviews, and focus group interviews (FGI) as methods of data collection. Fifty Acehnese adjectives extracted from the Swadesh list were tested to 10 younger speakers (age 13-14), who were selected out of 113 respondents who returned the questionnaires. The selection criteria are considered to include age, origin, and parents' origin. The respondents were all students of years 7 and 8 of a junior high school in a suburban area of Banda Aceh, considered the hot spot for the contact between Indonesian language speakers and Acehnese language speakers. Responses of the 10 participants interviewed were qualitatively analyzed to get the insights and circumstances of the use of the targeted adjectives.

Main Findings: The findings of this study show that $50 \%$ of the number of tested words was only known to $50 \%$ of the participants interviewed. While the other half of the participants show varied knowledge and understanding of the tested adjectives, the questionnaire response also indicates that these young speakers' rather negative attitudes toward the Acehnese point to the decreasing domains of language use.

Applications of this study: The finding of this study is expected to contribute to the field of sociolinguistics in the way that it informs about the status and vitality of Acehnese Language from the specific segment of its speakers, which can be taken into consideration in the language policymaking.

Novelty/Originality of this study: This study looks at which vocabulary items (from Swadesh list) are still known to the younger speakers of Acehnese. Specifically, this study focused on the adjectives in Acehnese, which are still familiar to the speakers and which are not.

Keywords: Language Loss, Acehnese, Adjectives, Language Attitude, Language Use.

\section{INTRODUCTION}

Indonesia is one of the biggest countries with the fifth largest population in the world. It harbors as many cultures, traditions, and local languages as the ethnic groups that call the country home. According to Ethnologue's record (Eberhard, 2019), there are 719 local languages spoken in Indonesia, each spoken by an ethnic group living in many different places in the archipelago. Twelve of these languages have died and no longer spoken.

Some languages which are still alive are only spoken by the elderly in their communities while younger speakers are no longer using the languages or use the languages in a very limited frequency and domain. According to Holmes (2008), if in a region all of the speakers die, the Language also dies. Holmes then took an example of this where Manx Language which was spoken by people in the Isle of Man which is bordered by England and Ireland. It completely died when its last speaker, Ned Maddrell, passed away. Even though this Language had been revitalized but it is proved that what Holmes said is true that a language can die when no one speaks that Language any longer. In other words, a language can be endangered when many people rarely use it to speak with others using the Language.

The local languages in Indonesia are for most cases the first languages of their speakers before the speakers are introduced to Indonesian, the national Language, at the start of their formal education. On the other hand, Indonesian, with about 250 million speakers which makes it the most widely spoken Language in Southeast Asia, is not acquired as the first Language by its speakers. Only about $20 \%$ of the speakers have Indonesian acquired as their first Language (Tadmor, 2009). As a language that exists with constant contact with Indonesian, Acehnese is continuously changing as a result of many factors including constant borrowing, the attitude of its speakers, and the competition for the domain of use. These phenomena are common in a speech community where bilingualism exists. Contact-induced change of a language is not a rare phenomenon as the most studied and the most used Language, English, for example, has changed the history as a result of its contact with other languages in its surrounding throughout history (Trudgill, 2016). This study specifically looked at the effect of the ongoing contact between Acehnese and Indonesian on the use of Acehnese adjectives by Acehnese younger speakers. 


\section{LITERATURE REVIEW}

\section{Language Change and Language Shift}

According to Trudgill (2016), one of the changes experienced as a result of the contact with other languages is a simplification that can constitute a reduced variation of the variables in a language. Trudgill further speculates that contact with different languages has resulted in the changes of different segments of the English Language with the influence of those different languages it had contact with. Its grammar has been influenced by Basque, phonology by Finnic and Basques, and its lexis by the Afro-Asiatic (Trudgill, 2016). Moreover, when variation exists in a language, changes are bound to take place. Variants of a single variable in the Language are competing to get their place within the repertoire of the speakers of the Language.

The existence of variations in a community of speech can be associated with the exposure, the knowledge, and the competence of the speakers in that community of more than one language or language varieties. When a speaker masters two languages, there is a possibility language shift to occur and this phenomenon has been explained by many scholars. Ravindranath (2009) pointed out that language shift occurs when the bilingual speakers stop using one of two languages that they have. It is the abandonment of a minority language by its speakers who prefer to begin using the majority language (Bolonyai, 1998; Letsholo, 2009). Factors leading to language shift can be economic, political which include migration, and social such as intermarriage (Holmes, 2008).

Language shift also occurs due to cultural history, socio-cultural, economic, and psychological as pointed out by Nawaz, et al. (2012). In the study of Punjabi language, they explained that colonization under the British rules that occurred in a country has resulted in the native Language of the country becoming an inferior language and was forced to use the Language of the colonial state. This has happened to the Punjabi language which has been shifted with the penetration of English into Punjab. In the socio-cultural side, English has been determined by most people as a more prestigious language compared to the Punjabi Language. Therefore, those who use English will get a privileged position. And for the Punjabi language it will continue to be marginalized, and eventually ignored by its speakers. As English has a higher role in the Punjab area, those who use English will find it much easier to get higher-level jobs while those whose Language is Punjabi, its speakers must learn to use English to get the job of the same prestige. Being under British rule made the use of English more dominant than the Punjabi language which led to Punjabi people believing that the Language of Punjabi to be a lowly language used by lower classes. English, on the other hand, is considered more superior and is exclusively used by people of higher classes. Therefore, Nawaz, et al. (2012) argued, slowly there will be a shifting of a language from Punjabi to English and ultimately, this can be a reason for Punjabi to disappear. This is in line with the general notion put forward by $\underline{\text { Argenté (1995) }}$ that language shifts can be a reason for a language to be extinct.

\section{Reason of Language Lost}

A multitude of factors has been attributed to language loss and these include lexical changes, the role of parents and children (family), and attitude of speakers. Lexical change can be one of the many causes that make a language extinct or die. Lexicon, as noted by Fromkin, et al. (2011), refers to the mental storehouse of information about words and morphemes, the smallest meaningful elements of Language. The knowledge of the meanings of these words and morphemes enables speakers of the Language to reciprocally convey messages and meanings. It is essentially the core elements of a language and thus, a loss of lexicon or its replacement with variants of a different language is a direct indication that the Language has started to cease to exist.

Lexical change can occur at a different level of the Language. Jendra (2010) noted that lexical changes can occur the level of word formation and borrowing, changes in sounds and spelling, changes in meaning, and even the disappearance of the items altogether (Jendra, 2010). A recent investigation of lexical change due to social contact in speakers of Pasè dialect, a variety of Acehnese (Rizka\& Zainuddin, 2016) identified changes ranging from lexical loss, borrowings, loanblend, and loan-translation. Furthermore, Jendra said that when some words are no longer used, it will be the culmination of lexical change. A language that keeps borrowing words from other languages is one cause of lexical change (Bloomfield, 1965). A study by Michael (2014) about Kisagalla and Kiswahili languages reveals that lexical change can occur if there is an assumption about 'modern' and 'primitive' from native speakers toward a language. This leads the speakers' preference to use a language that is perceived as more modern to the Language that is considered primitive. Michael also noted that intermarriages, urbanization, minority community, and gender can also cause lexical change (Michael, 2014), which is a phenomenon taking place with Kisagalla whose lexical items slowly change to Kiswahili.

The extinction of a language is also highly dependent on both the elders and children in a speech community. Even children have a vital role. According to Krauss (1992), a language is already threatened to their extinct when the children are no longer taught to use the Language. Krauss (1992) argues that children and elders are the main factors of a language becomes extinct. There are certainly many other factors that can bring a language to be disappeared but the role of the elders in deciding on the Language of the children is vital. Similar ideas were also expressed by Canagarajah (2008). The role of the family can lead a language to its safety or death. Canagarajah (2008) said that family has a vital role to protect the heritage language; even its effectiveness could surpass that of higher institutions. Fishman (1991) has 
also said something along this line suggesting it be much better of the use of mother tongue at home to maintain Language and to pass on the mother tongue through the next intergenerational transmission. Yusuf et al. (2013), based on their observation, also support the notion that children are likely to speak in their mother tongue language if their parents use the Language at home. Having to use the Language with their mothers and fathers and being able to witness the use of the Language by their parents can provide them with the opportunity to appreciate the Language and, therefore, can improve the attitude towards their mother tongues.

Speakers' attitude influences language use and it is one of the most important assets to maintain a language (Ravindranath, 2009). More specifically, as pointed by Letsholo (2009) and Garcia (2003), the attitude of the youth speakers is a significant factor in the Language. The young generation has a very important role in maintaining a language because they are responsible for passing down the legacy of the Language to generations after them.

\section{Acehnese Language}

Throughout its history, as English, Acehnese has experienced contact with many different languages. When its phonology, lexis, grammar, and some of its suprasegmental elements are examined, it can be speculated that Acehnese has been in contact with Malay, Chamic languages, Arabic, English, and Portuguese. These languages were in contact with Acehnese in different degrees, and some were in contact with Acehnese indirectly. Evidence of contacts with these languages can be found both in the historical accounts and the elements incremented in the Language (See Durie, 1985; Thurgood, 1999; Sidwell, 2005; Sneddon, 2003).

Among the languages in Indonesia, Acehnese is a local language that has a large number of speakers, though not considered a major local language. About 3.5 million people living on the northern tip of the Island of Sumatra speak the Language. Despite the large number, our observation indicates that the future existence of Acehnese might be at risk due to its decreasing domains of use.

We witnessed the phenomenon where many young people now prefer to use Indonesian to Acehnese. Previous researchers have also had this observation (Al-Auwal, 2007; Alamsyah, et al, 2011; Zulfadli, 2014; Aziz \& Amery, 2016; Aziz, et al., 2017). In his study of Acehnese speaking youths, Al-Auwal noted that they had rather a negative attitude towards Acehnese, their mother tongue when compared to Indonesian, the national Language of Indonesia prescribed as the Language of instruction in education. They viewed Acehnese as strange-sounding and rather rude but Indonesian as prestigious. In terms of preference, Zulfadli (2014) and Alamsyah et al. (2011) observed that many Acehnese families are now using more Indonesian at home than Acehnese, and this consequently poses threats to the stability of Acehnese Language. This attitude and language preference, and the speakers' negligence about using their Language can lead to the extinction of the Language and therefore, there is a need to call urgency to the situation and to start thinking about the language maintenance policy (Aziz \&Amery, 2016; Aziz, et al., 2017).

On the one side, it is undeniable that everyone should learn Indonesian as the official Language and the Language of wider communication, and that is an obligation. On the other side, Acehnese is the identity of the Acehnese people because everyone who was born in Aceh and by not being able to speak Acehnese, they will lose one of their important identities. The language preference or often termed as language choice of the young people may lead to shift their Language. This phenomenon can be a problem if it keeps continuing. Acehnese can disappear in the future as the number of its speakers continues to decline. A language can eventually die when everyone stops using it (Haynes, 2010).

Acehnese continues to experience changes and admittedly, the change is taking place from the points of view of both space and time as it always has since it split from its previous Aceh-Chamic group in mainland Southeast Asia hundreds of years ago (Thurgood, 1999;2007). From change over time, one can observe the difference between the Acehnese used in the past decades and one currently used. Durie's observation four decades ago suggests that one can notice the Language used by the older and younger generation is different in several small ways (Durie, 1985). From changeover space, one can notice the interaction between Acehnese and Indonesian. In remote and rural areas, Acehnese is still more dominant than Indonesian but the closer one gets to more urban places the less use of the local languages is encountered.

Recently, Acehnese has been in a critical state and categorized with the status Threatened ( $6 b)$ on AES language endangerment scale (Hammarström, et al., 2018, p. 371). This means, according to the scale, that Acehnese is "only used orally by all generations but only some of the childbearing generations are transmitting it to their children". AES stands for Agglomerated Endangerment Status. Ethnologue provides further details regarding the state of Acehnese in which it is described as shifting toward Indonesian, the national Language, especially in urban areas where Indonesian is preferred as the medium for communication. Furthermore, Ethnologue noted that a positive attitude is still displayed by some young speakers and adults (Eberhard, et al., 2019). However, as the situation is continuously changing, attitude and use of the Language of young people, the ones who are supposed to carry forward this heritage language, needs reexamination. Although the use of Acehnese and the language attitude of people, especially young people, in urban areas are not in favor of the Acehnese, this condition may also diffuse to suburban areas and eventually to remote villages in rural areas.

Another indication that a language is becoming endangered or threatened is when many of its native vocabularies are no longer (not often) used by its speakers. In the case of Acehnese, based on the researchers' observation, many Acehnese 
vocabulary items have been rarely used by the Acehnese speakers especially by the young and those who live in urban areas and areas within their vicinities. The example of those vocabularies is jeumot 'hard-working', ceudah 'beautiful', kanot '(cooking) pot', which are listed in the Acehnese Swadesh list.

\section{Adjectives in Acehnese: What is already known?}

In Acehnese, parts of speech deserve to be idiosyncratically described for the fact that it is often not possible to identify parts of speech based on their forms alone because the root forms are usually able to function directly as different parts of speech without morphological markings. Therefore, in their description, parts of speech should be approached based on both their syntactic function and their forms. Durie (1985, p. 44) took this approach in describing Acehnese parts of speech in his Acehnese grammar. An example of these is the word jeue 'caught with a net' which falls under the verb category. But it can also mean 'a type of net' which would then fall under the noun class.

The different syntactic function is not only confined to noun-verb interchangeability but also parts of speech. The word ngöncan serves three different syntactic functions referring to 'friend' (noun), 'with' (preposition), 'and' (conjunction); and therefore, it can be problematic when one has to group it into on part of speech.

This tendency also applies to adjectives and Durie did not even put adjectives as a class or a part of speech on its own because their identification heavily depends on the semantic ground (Durie, 1985). Durie admitted though that he pursued this approached to strictly follow the system of contrast. In morphology, 'contrast' is identified when two linguistic elements in the same environment(s), and replacing one with the other creates a difference in meaning. Two elements in identical environments make a minimal pair.

This study was intended to investigate words that are no longer used, reduced in variation, or already replaced by lexical items borrowed from other languages when the speakers use Acehnese. Since the size of this study is limited, the focus is only on the adjectives, identified based on its function following Durie's (1985) approach.

\section{METHODOLOGY}

This is a sociolinguistic study intended to explore more in-depth the ways adjectives in Acehnese were used and not used by the younger speakers of the Language. This research sought to understand participants' use of Language, especially on adjectives, their views on their use of the Language, and based on their response, predict the trajectory of the status of the adjective use and the Language in general. On the broader perspective this study fits into qualitative research which is an attempt to broaden and/or deepen our understanding of phenomena in our social world (Hancock, 2002), and in this case the language use phenomenon among younger speakers of Acehnese. The ways qualitative researchers gather data include asking people's views on something, finding out about some things that someone has experienced, asking sensitive questions, or investigating something new that was not there before, some of which were devised in this study.

This study was looking at how many adjectives in Acehnese that have the potential for loss. Students of a secondary school in the outskirts of Banda Aceh were taken as language sources. Many students in this school live in Aceh Besar and Banda Aceh where many people still understand and use Acehnese well in their daily life communication. However, because this area is within the suburb of Banda Aceh, the use of Indonesian in many cases can be more dominant than the use of the local Language, Acehnese.

Questionnaires, focus group interviews, and wordlist interviews were used as instruments to collect the background information of the sources and their language use. Questionnaires were distributed to 130 respondents of which 113 were returned. The questionnaires asked personal information such as their origin, the origin of their parents, the decision of language use when they talked, and so forth. Ten (10) participants were selected for focus group interviews and wordlist interviews based on their responses to the questionnaires following the set criteria.

After selected ten participants based on criteria in the questionnaires, they were interviewed. There were two types of interviews, Focus Group Interview (FGI) and Wordlist Interview. A focus group interview is one of the data collection techniques in qualitative research. A focus group, as stated by Anderson (1990), refers to a group comprised of individuals with certain characteristics who focus discussion on a given topic or issue. Denscombe (2007) further details on the size of the small group as a focus group. According to him, a focus group should consist of a small group of people, usually between six and nine in number brought together by a trained moderator, the researcher for most cases, to explore attitude and perceptions, feelings and ideas about a topic (Denscombe, 2007). Instead of nine, this research gathered ten participants in a focus group discussion lead by one of the researchers to explore not only their perceptions and attitude towards the languages but also to observe their use of language and language choice when talking about certain topics. The reporting of data gathered using this Focus Group Interview is done by combining the narrative summary with actual quotes from the participants to explain their opinions in their own words as suggested by Anderson $\underline{(1990)}$.

The questions consisted of 50 adjective items adopted from the Acehnese Swadesh wordlist compiled by Nabil Berri, an Acehnese language enthusiast (Berri, 2012). From the list, the focus was only on the adjectives, which were related to the topic of this study. Each participant had five (5) to ten (10) minutes to answer the questions. While FGI consisted of ten questions to verify, confirm, and expand on what was found in the wordlist interview. 


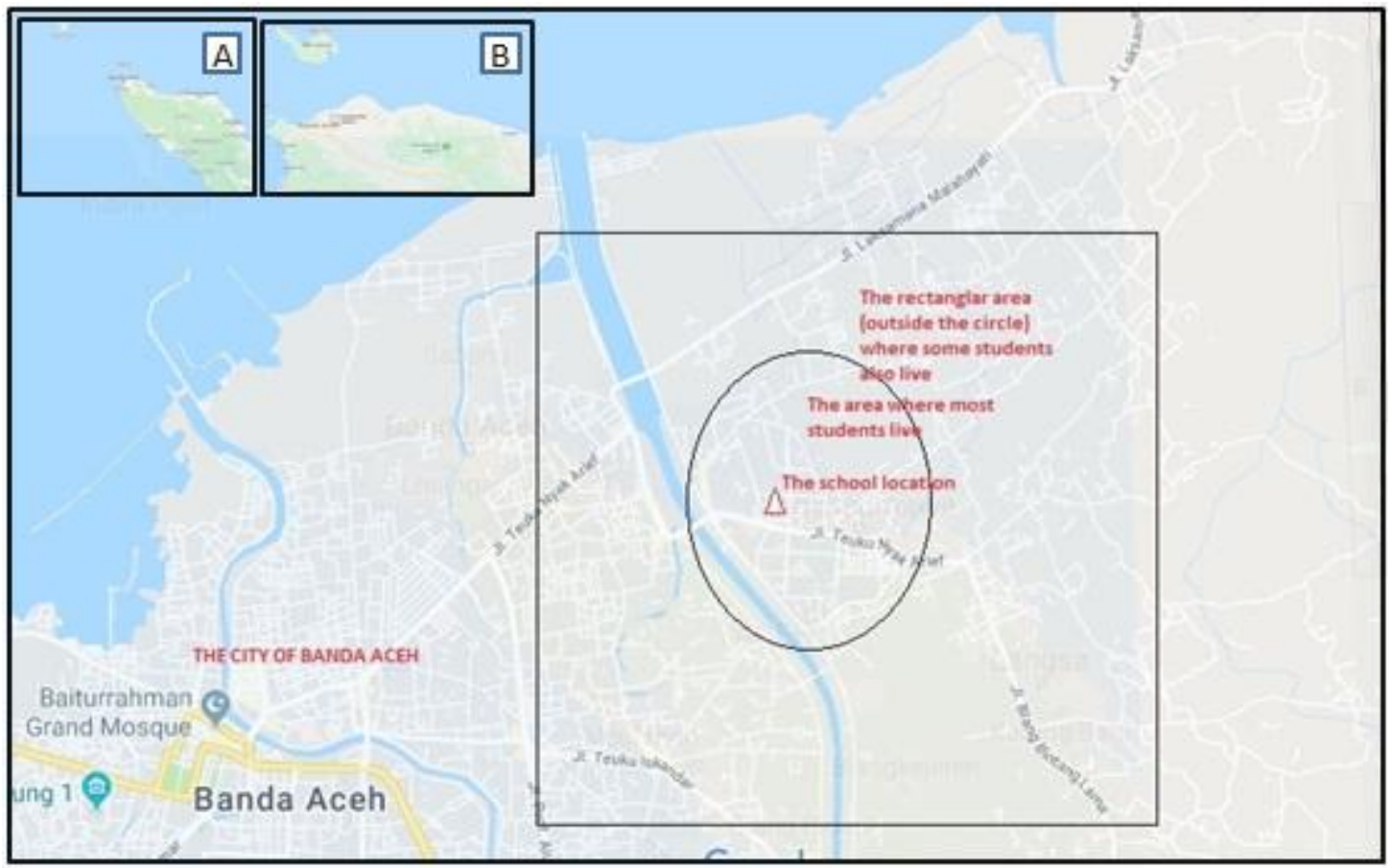

Figure 1: The location of the research

Source: Google map

Besides, the interview also inquired about participants' background to answer the second question of this study. Some questions that were asked such as place of birth, what Language that they use at home and school, their reason why they choose the Language to speak with their family and friends, and so forth.

To conduct this study, some steps were taken to analyze the data. First, the nature of adjectives in Acehnese was studied in terms of how it sits in the classification of parts of speech. Then, the adjectives included in the Swadesh list which have been compiled by Berri (2012) were extracted for the present study. Second, the adjectives were tested to the participants through interviews to find out adjectives which participants were able and not able to access.

Before interviewing the participants, questionnaires were distributed to get the students' responses. Questionnaires were distributed to 120 students of grade I and II at MTsN 4, Rukoh, Banda Aceh. Their age ranges from 13-14 years old. From the 120 questionnaires that were distributed, 113 were returned. The purpose of giving questionnaires was to get background information of the participants regarding their language use and the basis for selecting participants to be involved in the Focus Group Interview and Wordlist Interview.

Ten participants were selected consisting of six (6) female and four (4) male students. The selection of these ten participants was to further test the wordlist under study and their use of the words (adjectives). After questionnaires were returned, participants were interviewed as the second step to get the information. Two types of interviews were conducted, Focus Group Interview (FGI) and Wordlist Interview. Focus Group interview was undertaken on 5 May 2019 and lasted 42 minutes. The interviewers were facilitated by two teachers in the Mushalla 'prayer hall' of the school. All ten selected participants attended the FGI where they took turns answering ten questions prepared by the researchers.

In the wordlist interview, basic adjectives in Acehnese were tested. The interview lasted for about an hour to cover 50 lexical items. During interviews, a mobile device recorder was used. Notes were also taken to indicate words that participants had difficulty answering.

Data were classified into two groups. First, after interviewing with the participants, the results were divided into two parts. The first part contains the adjectives that are known by the participants and the second part contains the adjectives that are unknown to them. Second, the observation was made to identify and rate the adjectives based on their familiarity with the students. Inferences were then made for the prediction of the potentially lost adjectives.

\section{RESULTS}

\section{Questionnaires}

Questionnaires were distributed to gain sociolinguistic information on the participants. This information includes their background such as the year and the place they were born, where they live, and how many people they have in their family, family backgrounds such as the origin of their parents and the Language used at home. The questionnaires also asked about their language use with friends and teachers at school and included questions to assess their attitude to 
Acehnese Language and Indonesian. Some of these kinds of information were used to further select participants to be included in the Focus Group Interview (FGI).

\section{Personal Data}

Several questions in the questionnaires were to find out the age of students, their date of birth, their origin, and the origin of their parents. Based on the 113 returned questionnaires we learn that the students are of 12 to 14 years old, born in the years 2004, 2005, and 2006 and they are in the second year of their middle school (Second year of SMP in Indonesian system of education, eight graders for the equivalent in other systems such as the US and Australia). The majority of these students live in Aceh Besar District and the Township of Banda Aceh where they were also born. Some were born. Some were born there but one or both of their parents were from other districts townships in Aceh including Pidie, Pidie Jaya, Lhokseumawe, North Aceh, South Aceh, and West Aceh. Still, some others come from outside the Aceh Province such as North Sumatra with Bataknese ethnic majority, West Sumatra where Minang people live, and Bogor where Sundanese and a mixture of people from across Indonesia now reside. Although the latter group comprises of small number, they exert influence regarding language use.

\section{The Use of and Attitude to Language}

The following questions about students' background were several questions related to their language use and attitude to Language, in this case, Acehnese and Indonesian, the two languages competing for the domain entitlement within the sphere of bilingualism in Aceh in general. The students are bilingual with Acehnese being the mother tongue and Indonesian the Language of educational instruction. However, in addition to differences in intra-speaker and interspeaker language use and differences in their language attitude, the level of proficiency in each Language, especially Indonesian, the second Language of most of the participants is also arguably different from one student to the next due to the differences in their backgrounds. The use of Language here is when students communicate with others. Usually, one would use a certain language when interacting in certain domains. Then when interacting in another context or domain, they would use the other Language. This seems to be a common practice among the participants as revealed in responses in participant questionnaires as well as a focus group interview. In the discussion of this paper, it will be argued that this practice bears both positive and negative consequences to the speakers and the nature and existence of the languages of concern.

\section{On Language Use}

To obtain information on language use, the questionnaires have several questions relating to the participants' use of Language. Some of the questions asked students' use of Language when talking to their family, friends in their school, and teachers. From these questions, varied answers were found. Specifically, in the family, some students stated that they speak Acehnese and some use Indonesian with their family. Furthermore, it was also found that while the students use both Acehnese and Indonesian when interacting with friends, all of them use Indonesian when speaking to teachers except for one student.

The questionnaires also ask them to make a comparison of language use between Indonesian and Acehnese. The comparison was, in general, to compare and contrast their use in different domains such as in the family, at school, at home, or in other places. The answers were also found to vary where 70 percent of the students used Indonesian more, while 30 percent often use the Acehnese than Indonesian. However, especially at school, all students use Indonesian, not Acehnese. This is as mentioned in the previous where students should use Indonesian at school and also realized in their responses in the following paragraphs.

Language use in society applies to all categories of social grouping, age, sexes, and geography (Hickey, 2004). This translates to differences in the tendency of language use across younger and older people, males and females, and people living in rural and urban areas. According to Hickey $(2004$, p. 2), high amounts of language variation are induced in more urbanized areas where the concentration of people in such places enables more varieties from which speakers make their choice. The present research collected data from a school in Darussalam, a suburb of Banda Aceh, which can be categorized as an urbanized, if not urban, area. The use of Acehnese and Indonesian was shown to be domain-related for most students whose first Language is Acehnese. Acehnese is mostly home language while for social and educational purposes, Indonesian is used. Student MY6, for example, was born and lives in a village about one kilometer from the school, in Aceh Besar District. His response to the questionnaires demonstrated this domain-related use of Language.

(1) Saya berbicara bahasa Aceh (Hanya) dengan keluarga saya. Di luar itu saya berbahasa Indonesia. [I use Acehnese (only) in my family. Other than that, I speak Indonesian.] (MY6)

Some students, very few, demonstrated their use of Acehnese more than just at home. For them, Acehnese is also the Language that is used with their friends, in their village, and at school. The use of Indonesian is restricted to teachers and classroom interaction. An example of students belonging to this small group is HS11 who says:

(2) Saya lebih banyak menggunakan bahasa Aceh. [I use Acehnese more.] (HS11) 
HS11 also expressed his strong feeling about Acehnese and its use, especially revealed when he said in the comment section of the questionnaire answering the question about the Language used in daily life.

(3) Saya selalu menggunakan bahasa Aceh, dengan binatang pun pakai bahasa Aceh. [I always use Acehnese, even to animals I speak in Acehnese.] (HS11)

While HS11 is quite a promising case, despite rare, for the prospect of Acehnese, most of the participants' responses to the questions range from 'I use more Acehnese', 'I use more Indonesian' to 'I used only Indonesian'. Their reasons are varied, from the ease of using the latter Language to the accommodation to Language perceivably used by their counterparts such as friends and teachers at school. The three variations of response also show that participants who speak Acehnese also speak Indonesian, but participants who speak Indonesian speak very little to not at all Acehnese.

Most students also have a rather 'false' belief that all teachers at school are only able to speak Indonesian and therefore, all participants, as shown in questionnaire response, speak Indonesian with their teachers at school. The reason is both because they are obliged to use Indonesian with teachers (e.g. MH1) and their belief that all teachers only speak Indonesian (e.g. RM13). Asked which Language they use with their teachers and their reason; their response is Indonesian and the followings are what MH1 and RM13 wrote for reasons.

(4) Kar(e)na (Dengan) guru di sekola hsaya ... (dengan) guru semua (kami) harus berbicara bahasa Indonesia. [Because of (with) teachers at my school ... (with) all teachers (we) must use Indonesian.] (MH1)

(5) Karena kebanyakan guru saya hanya bisa bahasa Indonesia. [Because most of my teachers are only able to speak Indonesian.] (RM13)

The responses of the two participants indicate two things. First, the government policy to earthen Indonesian in the Educational sphere is gaining success. Second, success has led to students' false belief that their teachers only speak Indonesian. The reality is that more than 85 percent of teachers at the school where the study was conducted speak Acehnese as their first Language. The consequence of this reality is more in favor of Indonesian than Acehnese in terms of gaining domains of use.

\section{On Language Attitude}

The attitude of participants to both Acehnese and Indonesian is demonstrated in their response to questions asking about which Language they find more convenient speaking which was placed at the end of the questionnaire. Then, the Language intended on this topic was Indonesian and Acehnese. However, out of ten students, three of them answered that they preferred and felt more comfortable speaking in Indonesian, six students were comfortable to speak Acehnese and one student preferred to use both of the languages. Furthermore, these six students who prefer to use the Acehnese, the reason they describe is that the Language is easy to use as they are used to using it in daily life. Three students who chose to use Indonesian explained that Indonesian sounds more polite as well as easy to be used. While one student who uses both languages gave the reason that Indonesian and Acehnese are easy to use in daily conversation.

\section{Focus Group Interview}

Nine students of 13 years old and one of 14 were selected for the focus group interview. Their selection was also based on the place of birth or origin. The ten selected students were of Aceh origin, three of Aceh Besar, and seven of Banda Aceh. All of these students are native speakers of Acehnese. Although some students were not fluent in Acehnese, they could still speak in this Language. For example, there was one student who was not fluent in Acehnese but still could understand well when Acehnese was talked to him. The interview started with questions related to direction designation, weather conditions, teacher's character, friend's character, asking colors, and selecting words in numbers. The same questions were asked and phrased differently to the students to make the interview look like a more natural speech event.

Excerpt 1 Talking about weather targeting wie 'left' and uneun 'right'.

Interviewer: Biasa jih dari rumoh sikulanyoe, biasa adek ho rot woe?

[Usually from the school, which way do you take to get home?]

Student 1: Rot BlangKrueng.

[Through BlangKrueng.]

Interviewer: Leuhnyan ho rot lom.

[And then?]

Student1: Lewat Lambateueng.

[Past Lambateueng.]

Interviewer: Aleuh nyan ho lom? Dari BlangKrueng, nyan ho wét jih?

[Then? From BlangKrueng, which way do you turn?] 
Student 1: Wét wie leuhnyan teupat ju. Leuhnyan wet neun, baroe trok.

[Turn left and then just go straight. Then, turn right, and that's it (my place/home).]

Excerpt 2 Talking about whether targeting the word bulut ${ }^{\star}$ wet'.

Interviewer: Soe yang kajeuet ba Honda inoe? Sang kajeut mandum nyo? Nyoe aneuk agam kajeuet mandum ba honda nyo? Aneuk inong na yang hanjeut? Ok ka, meseu ba honda lam ujeun. Adek ba honda lam ujeun, peu ta mereumpok lam ujeunn yan? Hana pakèk mantel adek. Peu akibat jih, peu eeunteuk? Hana pakèk mantèl, hana pakèk helm.

[Who rides motorbike here already? I bet everyone does, yes? You boys ride motorbikes already, right? What about you, girls? Anyone still doesn't? Ok, now, let's say it's raining and you are on your bike, what will happen? You are not wearing your raincoat. What will happen? No raincoat, no helmet.]

Student 1: Basah.

[Wet.]

Interviewer: Meuseue adek akibat jih peu? Ta ba honda lam ujeun hana pakèk helm hana pakèk mantèl.

[What about you? What do you think? (to another student). You are on your bike in the rain, no helmet, no raincoat.]

Student2: Pertama basah, abis tu susah liat jalan nya karna gak pake helm, dah tu aja.

[One, you will get wet. Then, it is difficult to look through the road because you are not wearing a helmet. Ok that's it.]

Interviewer: Meuseu adek?

[You?] (to another student)

Student 3: Basah.

[Wet].

Interviewer: Leuh nyan peu lom?

[Then, anything else?]

Student 3: Hom nyan mantong.

[I can't think of anything else. That's it I guess.]

Excerpt 3 Talking about a person's character targeting the word get 'good'.

Interviewer: Nyoadek so guru favorit? Pelajaran peu?

[You, who is your favorite teacher? (Teaching) which subject?]

Student 7: Qur'an Hadits ngon Aqidah Akhlak.

[Quran and Hadits Studies and Aqidah and Akhlak Studies.]

Interviewer: Pakon adek galak?

[Why do you like (the subjects)?]

Student 7: $\quad$ Watee di jelaskan bagah di tamong lam ulè.

[When he/she explains (the lessons), it sticks to your head very quickly (easily).]

Interviewer: Kiban ureung gob nyan?

[What is he/she like (as a person)?]

Student 7: Get akai.

[(He/she is) very kind.]

Excerpt 4 Talking about a person's character targeting the word brôk 'bad' and jeuheut 'evil'.

Interviewer: Nyo droneuh soe nyang hana galak? Kon hana galak, tapi kureung nyaman tameungon.

[You, who don't you like (as a friend)? Not 'don't like', but just a little uncomfortable to be friends with.]

Student 9: Na sidroe, awak agam. 
[There's one, it's a boy/a guy.]

Interviewer: Pakon? [Why?]

Student 9: Jih ureung jih meunoe, galak that di ma'èn ngon awak inong. Meunyoe ka di ma'èn ngon awak inong tuwo jih keu tanyoe.

[So, this is what he does. He likes to hang out with girls all the time. When he's is with girls, he forgets us.]

Excerpt 5 Talking about color.

Interviewer: Adek galak warna peu?

[What color do you like?]

Student 5: Dongker.

[Navy.]

Interviewer: Jadi dongker peu-peu mantong na?

[So how many shades of dongker are there?]

Student 5: Biru.

[Blue.]

Interviewer: Selaen biru dongker?

[Other than blue navy?]

Student 5: Warna hijau toska.

[Tosca green.]

Interviewer: Kiban warna jih ijo toska?

[What does toska green look like?]

Student 5: Warna jih cerah.

[It's rather bright.]

Interviewer: Aleuh nyan warna peu lom?

[Then, what other colors are there?]

Student 5: Itam.

[Black.]

Excerpt 6 Talking about weight and height targeting number words.

Interviewer: Nyoe adek padum brat badan?

[You, what is your weight?]

Student 4: Segohlom jih satu lima satu.

[Last time, it was one five one.]

Interviewer: Hah?

[Huh?]

Student 4: Seratus lima puluh satu senti.

[(it's) one hundred fifty-one centimeters.] (She misunderstood the question for weight)

Interviewer: Nyoe brat?

[What about weight?]

Student 4: Tiga sembilan.

[Three nine (kilograms)] 


\section{Wordlist Interview Session}

As mentioned earlier, when the ten students were interviewed, 26 words were not answered from the 50 words listed. Of these 26 words, each word has one or more students who cannot answer it. In other words, the words which fewest that could not be answered by students are one person, in each word. While some of the most unanswered words are ten students or all of them.

Table 1: Words not known to the students and the number of students not able to answer them

\begin{tabular}{|c|c|c|c|}
\hline No & The adjectives & The meanings & Number of students not being able to answer \\
\hline 1. & kuto & 'dirty' & 1 \\
\hline 2. & rayëk & 'big, large' & 1 \\
\hline 3. & teubai & 'thick' & 1 \\
\hline 4. & baro & 'new' & 1 \\
\hline 5. & gèt & 'good' & 1 \\
\hline 6. & brôk & 'bad, ugly' & 1 \\
\hline 7. & tajam & 'sharp' & 2 \\
\hline 8. & paneuk & 'short' & 2 \\
\hline 9. & sijuk & 'cold' & 3 \\
\hline 10. & geuhon & 'heavy' & 3 \\
\hline 11. & luwah & 'wide' & 3 \\
\hline 12. & keumong & 'swollen' & 4 \\
\hline 13. & raya & 'huge' & 4 \\
\hline 14. & ong & 'blunt' & 5 \\
\hline 15. & tumbôn & 'fat, chubby' & 5 \\
\hline 16. & tumpôi & $\begin{array}{c}\text { 'blunt (opposite of } \\
\text { sharp)' }\end{array}$ & 6 \\
\hline 17. & chik & 'adult, old' & 6 \\
\hline 18. & ban & 'new, just now' & 6 \\
\hline 19. & pijuet & 'thin (opposite of fat)' & 6 \\
\hline 20. & ubeut & 'little, small' & 7 \\
\hline 21. & got & $\begin{array}{l}\text { 'good (a variant of } \\
\text { getting)' }\end{array}$ & 7 \\
\hline 22. & ch'èk & $\begin{array}{l}\text { 'small, young (for a } \\
\text { person)' }\end{array}$ & 9 \\
\hline 23. & bulut & 'wet' & 10 \\
\hline 24. & 'èt & $\begin{array}{l}\text { 'short (a variant of } \\
\text { paneuk)' }\end{array}$ & 10 \\
\hline 25. & arat & 'tight' & 10 \\
\hline 26. & jeuheut & 'evil' & 10 \\
\hline
\end{tabular}

Furthermore, based on the information from the table these words were categorized into two parts, safe words and those considered being endangered. As for the safe words section, there are fifteen items where one to five students could not answer. The other thing that could be seen is that in the common side these words are still very often used in daily conversations such as kuto 'dirty', rayeuk 'big', and baro 'new', etc. Therefore, the fifteen words can still be categorized as safe words or have little chance of being lost.

Meanwhile, as many as eleven words can be categorized into insecure parts where six to ten students don't know. Also, if we look at it from the other side, there are a few words that are rarely used in daily conversations, especially among children and adolescents. Those words are 'et, arat, bulut, and so forth. The eleven words can be categorized as unsafe words and have big potential to be lost, especially these four words bulut, 'et, arat, jeuheut, where ten students or all students interviewed could not be answered by them.

\section{Attitude to Acehnese}

After the wordlist interview, their assumption of Indonesian and the Acehnese was enquired. The purpose was both to verify the information obtained earlier given in the questionnaire and to find out the answers to the second research question of this study. The attitude of the speakers toward the Language is very important. As mentioned by Ravindranath (2009), the speakers' attitude will influence language use and is one of the most important things to maintain a language. A language will stay alive when its speakers have a positive attitude towards the Language. On the contrary, a language can be abandoned when its speakers have a negative attitude. This question was directly asked one by one to students so that students gave their serious responses without much influence from other friends.

These are answers from three random participants about their assumption of Acehnese. 
Excerpt 7 Bahasa Aceh digunakan untuk ulok-ulok. [Acehnese is used for mocking] Bahasa Indonesia digunakan waktu lagi serius. [Indonesian is used in serious situation.]

Excerpt 8 Bahasa Indonesia lebih sopan dan lebih enak didengar. [Indonesian is more polite and much more pleasant to listen to]

Excerpt 9 Bahasa Aceh itu lebih mudah. [Acehnese is easier] Tapi bahasa Aceh kurang sopan disbanding kan dengan bahasa Indonesia. [But it is less polite compared to Indonesian]

This shows that, even though most students are more comfortable in using Acehnese to Indonesian, their assumption on Indonesian is different which they stated that the Language sounds more polite rather to Acehnese.

\section{DISCUSSION}

The linguistic environment in Indonesia is extremely complex with some 700 local languages existing alongside the national Language, Indonesian. The majorities of Indonesians speak one of these local languages as their first Language and begin the formal study of the national Language in school (Fanany, 2015). While there is an imminent need for Indonesians to be able to function in Indonesian to be able to participate fully at the national level, this process should not be at the cost of losing their first Language.

One of the causes of the disappearance of a language is the occurrence of lexical change. Jendra (2010) explained that there are several stages in which lexical changes can occur: borrowing words, sound and spelling changes, and meaning changes. Meanwhile, Bloomfield (1965) stated that lexical change occurs due to the continuously borrowing words from other languages. During the FGI several students sometimes used several Indonesian words although the FGI was carried out in Acehnese. As occurred in conversation 13 when the interviewer asked student 5 about his/her favorite color, the student answered by saying the dongker and hijautoska. Meanwhile, in conversation 16 the similar was given when student 1 responded to questions from the interviewer in Indonesian though then he/she changed it to Acehnese when reasked for confirmation.

Moreover, Canagarajah (2008) stated that family is the main factor to protect the mother tongue especially since the Language appears to be endangered. Fishman (1996) even asserted that the mother tongue should be preferred in interacting with family as this can make it easier to transmit it to the next generation and can even maintain the Language from the threat of extinction. Canagarajah (2008) and Fishman (1996) statements can also be understood that language skill was started from the family. This then depending on what Language he/she will use with his/her family, whether their mother tongue or another language, he/she will be very good at using it as the Language will be the first Language for him. Certainly, and normally a person is more adept at using his/her first Language than the Language he knew afterward.

However, when information about students' languages uses with their family were collected, eight students often spoke Acehnese with their family, while two of them acknowledged using Indonesian more often when interacting with their family. Specifically, for both students, it proved what Canagarajah (2008) and Fishman (1996)had stated where one of two students seemed difficult to respond to questions in Acehnese. They clearly understood questions asked to them in Acehnese, but it was either they had difficulty or reluctance to answer them in the same Language. They said they spoke Indonesian too often.

Furthermore, the attitude towards a language will make someone compelled to use it as often as possible, or even vice versa, he/she will not use it at all. If someone's attitude towards a language is good then he/she will feel comfortable using it. But instead, he/she refused to use the Language. As stated by Al-Auwal (2017) most people today, especially young people, consider Acehnese sounds strange and rude compared to Indonesian. A similar tendency was also found in all the students that had been chosen to be interviewed in this study and they assumed that Indonesian sounds more polite than does Acehnese. However, it cannot be denied that this assumption reaffirms what Al-Auwal (2017) has observed that most young people now assume that the Acehnese Language is less prestigious than Indonesian.

This study found that the three factors were the most dominant among the participants and the factors seem to play major roles for the prediction of the language change, especially in this case the disappearance of some of the adjectives in Acehnese. A special note should be placed on the evaluation of Acehnese by these participants where most of them rated Indonesian higher than Acehnese. Lower evaluation of Acehnese, their first Language, seems to also influence their capability in their use of their first Language. While most participants were able to express their response in Acehnese, one female student, for example, had difficulty in responding questions asked in Acehnese which is a sign of degradation in her first language competency, or lack of willingness to use it, which can be associated with a less positive attitude towards their first Language. Other female students were also found to have a similar tendency for the reluctance of using Acehnese as showed in their response to questionnaires, If this phenomenon continues, a fair prediction is that the use of Acehnese will also continue to decline especially in more urbanized areas of Banda Aceh and its vicinity which include some areas of Aceh Besar. This further confirms the idea put forward by Labov (1990) based on their Philadelphia study that women are the main active agents of language change and therefore, their language behaviors are important to study, and in this case, we would argue also important for the case of Acehnese, to have an idea of the trajectory of language change and shift of the Language. 


\section{The Domain of Language Use}

Indonesian is the national Language of Indonesia, and therefore, the policy is Indonesian is the compulsory Language of instruction in every school in the country, both remote places and urban areas, including Aceh. As noted in our early work (Kismullah, 2017), there are differences in the intensity of using Indonesian between schools in rural and urban areas. Schools in towns provide their students with exposure to Indonesian and the opportunity not only to hear the Language spoken but also to use Indonesian in real communication with other students and teachers. Schools in rural areas are different. While the textbooks are all in Indonesian, the Language of instruction used by teachers is mostly Acehnese. Therefore, compared to students in cities, children living in rural areas tend to speak less Indonesian and more Acehnese. Although Acehnese is used almost all the time in rural communities, formal settings may still allow for some exposure to Indonesian formal language usage generally includes a great deal of code-switching to Indonesian. Such domains include Friday sermons, wedding speeches, and Maulid celebration speeches. On such occasions, codeswitching into Indonesian occurs very frequently (Kismullah, 2017, pp.38-39).

With the knowledge of differences in terms intensity between the use of Indonesian school both in rural areas and towns, the differences of use sought in this study were in smaller contexts, the commonly observed parameters for language use is the domain of language use. As this study was conducted in more urbanized areas rather than rural, the result seems to show more variation of the Language used by the participants in different language domains. The focus was placed on use at school and in the family. The result is, most of the students use Indonesian in their school alongside Acehnese. This dominant use of Indonesian refers more when they are interacting with teachers. With friends, Indonesian was still dominantly used, although occasionally Acehnese was also used.

Furthermore, with family, based on the data seven students used Acehnese, three students used Indonesian. This shows that the use of Acehnese with family is still dominant. This sounds to be contrary to the notes of Zulfadli(2014) and Alamsyah et al. (2011) but still, it indicates the beginning of the shift of the Language. Even, one student used both of the languages with family. The policy of the government that encourages the use of more Indonesian and makes it compulsory in places like schools or government offices makes Acehnese gradually abandoned. As many speakers are now more used to basah (item borrowed from Indonesian for 'wet') than bulut (the Acehnese version), it will not be far in the future from now that the adjective bulut will disappear from the repertoire of Acehnese speakers.

\section{CONCLUSION}

From the interview, 26 out of 50 words were found to be unknown by the students. These words that were unknown to some of the students were then put into two categories, namely safe word, and endangered words. From both categories, there are fifteen words unknown from one to five students. This is included in the safe word category as there were no more than five students who did not know about it. There are eleven words in which more than five students do not know. In other words, in each word, there are six to ten students who didn't know it. Then the eleven words are included in the endangered category.

Furthermore, one factor is the loss of a language due to a lack of communication with the family using certain languages. As Canagarajah (2008) and Fishman (1996) described that fewer people communicate using a language with family, the more possible a language can disappear, especially the mother tongue. Possible projection is possible to smaller elements/segments of a language such as vocabulary and in this case, adjectives. At least, there are few words or terms that will be ignored as they rarely communicate with family using a certain language. Moreover, the attitude of people towards a language will also determine whether the Language is safe or endangered. This was explained by AlAuwal(2007) regarding the attitudes of adolescents to Acehnese. The worse the attitude of people towards a language, the more threatened a language is. A bad attitude towards a language is like thinking that Language sounds harsh, weird, not modern, etc. when compared to other languages.

However, in the end, all students answered that Indonesian sounds more polite than Acehnese. In other words, the students assumed that the Acehnese Language sounded coarser than Indonesian. By that assumption, the writer believes that Acehnese will be abandoned slowly due to negative attitudes from people, especially in adolescents. Besides, a language will continue to exist if the adolescents still use it because they will be the ones to transmit it to the next generation. While the idea that the changes and metamorphoses of a language belonging to the law of nature or part of natural processes as a result of its absorption of new information and adaptation to the new conditions which has been iterated over and over again, including as recent as notes by Kuprieva, et al. (2019), cannot be truer, human beings, the owners and speakers of the Language are entitled to react to the change for their own sake. After all, as mankind has improved their knowledge, science, and technology, we have many times defied some of the 'curses of nature', such thing as both trivial and life-changing at the same time as contraception, for the betterment of human life. When such an intervention has been demonstrated possible, with sufficient reasons and motivation, the 'curse of language shift' is also possible to be intervened for the good sake of their speakers to preserve their identity and legacy, and in general for the preservation of diverse knowledge of the world. 


\section{LIMITATION AND STUDY FORWARD}

No study covers all aspects of the research problem. This study is only limited to subjects of students at the secondary schools in the outskirts of Banda Aceh and Aceh Besar. Future research is expected to collect data from more subjects all over Aceh to further gain information on the disappearing Acehnese adjectives among Acehnese young speakers.

\section{AUTHORS'CONTRIBUTION}

The first author of this article was responsible for and involved in the entire process from designing the project from planning, data collection, analysis, and the writing up. The second and third authors assisted the first author in the process. The second author's main contributions were advising on literature review along with following up on feedback from the editors and reviewers. The third author's involvement was mainly during data collection which includes communication with participants and data verification.

\section{REFERENCES}

1. Al-Auwal, T. M. R. (2017). The reluctance of Acehnese YOUTH TO USE Acehnese. Studies in English Language and Education Journal, 4(1), 1-14. https://doi.org/10.24815/siele.v4i1.7000

2. Alamsyah, T., Taib, R., Azwardi\&Idham, M. (2011). Pemilihan Bahasa Indonesia sebagai Bahasa Pertamaanakdalamkeluargamasyarakat Aceh penutur Bahasa Aceh di Nanggroe Aceh Darussalam [Choosing Indonesian as the children's first language in the family of the Acehnese community who is Acehnese native speakers in Nanggroe Aceh Darussalam]. Jurnal Pendidikan Bahasa Melayu, 1(2), 31-34.

3. Anderson, G. (1990). Fundamentals of educational research. The Falmer Press.

4. Argenté, J. A. (1995). Language shift: An overview. Catalan Review, IX (2), 39-59.

5. Aziz, Z.A., Yusuf, Y.Q., Raisha, S. \&Kamaliah, N. (2017). Language maintenance of the Tionghua speakers towards their heritage language in Aceh. International Seminar on Sociolinguistics and Dialectology: Changes and Development of Language in Social Life (pp. 278-283). Universitas Indonesia, Jakarta.

6. Aziz, Z. \& Amery, R. (2016). The effects of linguistics tsunami on the Language of Aceh. Studies in English Language and Education, 3(2), 100-108. https://doi.org/10.24815/siele.v3i2.4958

7. Berri, M.N. (2012). Swadesh word list - Acehnese. https://bahasaaceh.files.word press.com/2012/07/acehnese_swadesh_word_list.pdf

8. Bloomfield, L. (1965). Language history from Language. Holt, Rinehart, and Winston Inc.

9. Bolonyai, A. (1998). In-between languages: Language shift/maintenance in childhood bilingualism. International Journal of Bilingualism, 2(1), 21-43. https://doi.org/10.1177/136700699800200102

10. Canagarajah, A. S. (2008). Language shift and the family: Questions from the Sri Lankan Tamil diaspora. Journal of Sociolinguistics, 12(2), 143-176. https://doi.org/10.1111/j.1467-9841.2008.00361.x

11. Denscombe, M. (2007). The good research guide for small-scale social research projects, $3^{\text {rd }}$ ed. McGrawHill.

12. Durie, M. (1985). A grammar of Acehnese, on the basis of a dialect of North Aceh. Foris.

13. Eberhard, D.M., Simons, G. F., \&Fenning, C. D. (Eds). (2019). Ethnologue, the Language of the world, $22^{\text {nd }}$ ed. SIL International.

14. Fanany, R. (2015). Language background and language mastery in Indonesia: Implications for the maintenance and teaching of the national Language. Proceedings of the International Seminar on Languages and Arts (ISLA 4) (pp. 12-19), University of Padang, Padang.http://dro.deakin.edu.au/view/DU:30079347

15. Fishman, J. A. (1996). Language maintenance and language shift as a field of inquiry: A definition of the field and suggestions for its further development. Linguistics, 2(9), 32-70. https://doi.org/10.1515/ling.1964.2.9.32

16. Fishman, J. A. (1991). Reversing language shift: Theoretical and empirical. Foundations of assistance to threatened languages. Multilingual Matters, Ltd.

17. Fromkin, V., Rodman, R., and Hyams, N. (2011). Introduction to Language, $9^{\text {th }}$ ed. Wadsworth Cengage Learning.

18. García, M. (2003). Recent research on language maintenance. Annual Review of Applied Linguistics, 23, 2243. https://doi.org/10.1017/S0267190503000175

19. Hammarström, H., Castermans, T., Forkel, R., Verbeek, K., Westenberg, M. A., \&Speckmann, B. (2018). Simultaneous visualization of language endangerment and language description. Language Documentation \& Conservation, 12, 359-392.

20. Hancock, B. (2002). An introduction to qualitative research. UK Trent Focus Group.

21. Haynes, E. (2010). What is language loss? Heritage Briefs.h ttp://www.cal.org/heritage/pdfs/what-islanguage-loss.pdf

22. Hickey, R. (2004). Legacies of Colonial English. Cambridge University Press. https://doi.org/10.1017/CBO9780511486920

23. Holmes, J. (2008). An introduction to sociolinguistics, $3^{\text {rd }}$ ed.Longman.

24. Jendra, I.M. (2010). Sociolinguistics: The study of societies' Language. Grahallmu.

25. Kismullah, K. (2017). Dialect features of Leupueng children: A study of dialect in post-tsunami Aceh. (Doctoral dissertation). Deakin University, Melbourne. 
26. Krauss, M. (1992). The world languages in crisis. Language, 68(1), 4-10. https://doi.org/10.1353/lan.1992.0075

27. Kuprieva, I.A., Smirnova, S.B., Pugach, V.S., Belkina, I.V., Yatsenko, Y.N., \& Kazantsev, D.V. (2019). Non-language factors and language evolution. Humanities \& Social Sciences Review,7(4), 1329-1335. https://doi.org/10.18510/hssr.2019.74185

28. Labov, W. (1990). The intersection of sex and social class in the course of linguistic change. Language Variation and Change, 2, 205 54. https://doi.org/10.1017/S0954394500000338

29. Letsholo, R. (2009). Language maintenance or shift? Attitudes of Bakalanga youth towards their mother tongue. International Journal of Bilingual Education and Bilingualism, 12(5), 581-595. https://doi.org/10.1080/13670050802153459

30. Michael, I.K. (2014). Lexical change: A case study of Kisagalla losing its words to Kiswahili. (Master's thesis). University of Nairobi, Nairobi.

31. Nawaz, S., Umer, A., Anjum, F., \& Muhammad, R. (2012). Language shift: An analysis of factors involved in language shift. Global Journal of Human Social Science Linguistics and Education, 12(10), 73-80.

32. Ravindranath, M. (2009). Language shift and the speech community: sociolinguistic change in a Garifuna community in Belize. (Master's thesis). University of Pennsylvania, Philadelphia.

33. Rizka, B., \& Zainuddin. (2016). Lexical change with reference to social contact among the speakers of Pasè dialect. Lingua Didaktika: Jurnal Bahasa dan Pembelajaran Bahasa, 10(1), 1-8. https://doi.org/10.24036/ld.v10i1.6296

34. Sidwell, P. (2005). Acehnese and the Aceh-Chamic language family. In A. Grant \& P. Sidwell (Eds.), Chamic and beyond: Studies in mainland Austronesian languages (pp. 211-246). Canberra: Pacific Linguistics.

35. Sneddon, J. N. (2003). The Indonesian Language: Its history and role in modern society. Griffin Press.

36. Tadmor, U. (2009) Malay-Indonesian. In B. Comrie (Ed.) The world's major languages (pp. 791-818). New York, Routledge.

37. Thurgood, G. (1999). From ancient Cham to modern dialects: Two thousand years of language contact and change. University of Hawai'i Press.

38. Thurgood, G. (2007). The Acehnese: Genetic affiliations, diversity, and absorption. Paper presented at The First International Conference on Aceh and Indian Ocean Studies. UniversitasSyiah Kuala, Banda Aceh.

39. Trudgill, P. (2016). Contact-related processes of change in the early history of English. In M. Kytö\& P. Pahta (eds), The Cambridge handbook of English historical linguistics (pp. 318-334). Cambridge: Cambridge University Press. https://doi.org/10.1017/CBO9781139600231.020

40. Yusuf, Y. Q., Pillai, S., \&Ali, N. A. M. (2013). Speaking Acehnese in Malaysia. Language and Communication. 33, 50-60. https://doi.org/10.1016/j.langcom.2012.08.004

41. Zulfadli. (2014). A sociolinguistic investigation of Acehnese with a focus on West Acehnese: A stigmatized dialect. (Doctoral dissertation). University of Adelaide, Adelaide. 